\title{
Overview of Health Care Expenditure \& Healthcare Payment Methods in India
}

\section{Dhasarathi Kumar ${ }^{1 *}$ and Shiny Sohal ${ }^{2}$}

${ }^{1}$ Department of Public Health, SRM University, Chennai, Tamilnadu, India

${ }^{2}$ Indian Institute of Public Health, SCTIMST, Trivandrum, Kerala, India

\section{Background}

Any expenditure which is spend over the health and health care is defined as health care, expenditure [1]. Catastrophic Health Expenditure (CHE) is described as when family spent large amount which is equal to $40 \%$ or more than $40 \%$ of the household's income to the health care services, which may end in poverty [2-8]. Globally, around 150 million people face financial catastrophe in every year and due to Out Of Pocket payments made for health care about 100 million suffer impoverishment [9]. Worldwide one of the major aims of the health care system is not only providing the preventive and curative care it also includes the proper funding mechanism to an individuals to acquire health care [10]. Increasing catastrophic health expenditure among households may lead to the financial risk and financial insecurity. There are eight basic health care payment methods available in the world, these methods are more specific [11].

The availability of health services requiring payment, the lack of prepayment or health insurance, and low capacity to pay are the three key preconditions for catastrophic payments [2]. By increasing health care prices will not decrease the total health care demand, due to this the income-depressing effect may take place [12], and because of high medical fees many households not able to use medical services and without getting proper advice from the professional also they tend to take self-medication's which may lead to the drug resistance [13]. In previous studies, it has been found that client with different types of health insurance differs in their access to health services [14]. There is a strong relationship between increased pooled resources and improved Universal Health Coverage performance [15].

\section{Types of Health Insurance Schemes in India}

There are various types of health insurance schemes existent in India includes Taxed based funding, Private health insurance, donors, Medical saving accounts. Community health insurance, commercial insurance and social insurance [9]. The coverage under various community health insurance schemes is 30-50 million (Table 1) [16].

\section{Rashtriya swasthya beema yojna}

India recently introduced national social insurance programme which is called Rashtriya Swasthya Beema Yojna (RSBY), it helps to protect the poor/ Below Poverty Line household from health care catastrophic expenditure.

\section{Fee for service model}

Under this open-ended fee-for-service model, the agents determine the nature and quality of health services (i.e., the patients and the physicians) and face little in the way of financial consequences. The Prospective or contract approach involves agreement between purchaser and provider regarding the terms and conditions of payment and provides more explicit specifications of the volume and quality of care. There is also an integrated approach combining the roles of purchaser and provider under a single institutional umbrella (e.g., a local or central government). These approaches reduce the catastrophic expenditure will provide patients benefit, payers benefit and health providers benefit [17]. In prospective payment method, the rate for defined set of services is determined before the treatment takes place and in retrospective the rate is determined during and after the services are provided. In prospective method healthcare provider carries some degree of financial risk of exceeding cost than anticipated amount, thus consequences are borne by provider. To reduce cost incentive is provided to provider but this may risk on quality while contrary in retrospective payments the financial risk rests with the payer, tends to be cost enhancer and may promote over servicing. There is no marked incentive to reduce costs. The common provider payment mechanisms are budget, capitation, and fee-for -service, pay for performance, salary, and diagnosis-related groups [18]. In line item budget the provider is paid an amount per given period (usually a year) for a defined responsibility of service provision [19]. The total amount is broken down into items such as salaries, drugs, equipment, maintenance etc. Line item budgets are typically provided by governments for publicly run facilities with no purchaser-provider split. A Capitation is a form of budgeting in which the budget is based on a fixed fee for each enrolled person to cover a specified level of health care, regardless of the amount of service actually provided [17]. Capitation is a prospective method, is favorable to the provider because it guarantees revenue of defined period and also facilitates cost control. To monitor utilization and to curb under servicing each beneficiary should enroll with a provider. The per-diem payment methods includes inpatient services, the fixed amount is provided to the patient the day in a hospital, without keeping into account hospital's charges or costs acquired for care given to that patient. This method of payments has accounted for administrative standardization, with supporting software for coding and billing. The weakness lies in that, hospitals are provided with no incentive to avoid unnecessary days during hospitalization. Much transparency is not provided about hospitals' actual clinical activities in this system of payment [20].

In fee for service method payment is done per unit of service and provider is paid according to number of service items delivered. The three primary methods of fee-for-service reimbursement are cost based, charge based, and prospective payment. The provider gets reimbursed by the payer in cost-based method of reimbursement, for the costs that occurred in providing services to the insured beneficiaries. There is

*Corresponding author: Dhasarathi Kumar, Department of Public Health, SRM University, Chennai, Tamilnadu, India, E-mail: dhasarathykumar@gmail.com

Received May 28, 2018; Accepted June 25, 2018; Published June 29, 2018

Citation: Kumar D, Sohal S (2018) Overview of Health Care Expenditure \& Healthcare Payment Methods in India. Health Econ Outcome Res Open Access 4: 154. doi: $10.4172 / 2471-268 \times / 1000154$

Copyright: ( 2018 Kumar D, et al. This is an open-access article distributed under the terms of the Creative Commons Attribution License, which permits unrestricted use, distribution, and reproduction in any medium, provided the original author and source are credited. 
Citation: Kumar D, Sohal S (2018) Overview of Health Care Expenditure \& Healthcare Payment Methods in India. Health Econ Outcome Res Open Access 4: 154. doi: 10.4172/2471-268x/1000154

Page 2 of 6

\begin{tabular}{|c|c|c|c|c|c|c|}
\hline S. No & States & $\begin{array}{l}\text { Rsby \& State } \\
\text { Scheme }\end{array}$ & Insurance Scheme & $\begin{array}{l}\text { Launched } \\
\text { Date }\end{array}$ & Covered Population & Benefit Package \\
\hline 1 & $\begin{array}{l}\text { Andaman And Nicobar } \\
\text { Islands (Union } \\
\text { Territory) }\end{array}$ & No & $\begin{array}{l}\text { Andaman \& Nicobar } \\
\text { Islands Scheme For } \\
\text { Health Insurance } \\
\text { (Anishi) }\end{array}$ & 26.01 .2015 & $\begin{array}{l}\text { The Health Insurance Scheme will provide } \\
\text { coverage to those people belonging to } \\
\text { BPL category of A\&N Islands, Pensioner } \\
\text { settled in A\&N Islands after retirement and } \\
\text { their dependent family members \& Permanent } \\
\text { residents with family income of less than Rs. } \\
\text { 3.00 Lakhs per annum. }\end{array}$ & $\begin{array}{l}\text { ANISHI is to provide better } \\
\text { treatment for the needy } \\
\text { Islanders. }\end{array}$ \\
\hline 2 & Andhra Pradesh & No & $\begin{array}{l}\text { Ntr Aarogya Raksha } \\
\text { Scheme }\end{array}$ & 01.01 .2017 & $\begin{array}{c}\text { The BPL families and families coming under } \\
\text { employees and pensioners health scheme and } \\
\text { working journalist health scheme are already } \\
\text { covered with quality health care }\end{array}$ & $\begin{array}{l}\text { End-to-end cashless services } \\
\text { for identified } 1044 \text { diseases } \\
\text { under secondary and tertiary } \\
\text { care through } 400 \text { Government } \\
\text { and Corporate Network } \\
\text { Hospitals. }\end{array}$ \\
\hline 3 & Arunachal Pradesh & No & $\begin{array}{l}\text { Arunachal Pradesh } \\
\text { Chief Minister's } \\
\text { Universal Health } \\
\text { Insurance Scheme } \\
\text { (Apcmuhis) }\end{array}$ & $\begin{array}{l}16 \text { September } \\
2014\end{array}$ & $\begin{array}{l}\text { The scheme is unique in nature by providing } \\
\text { cashless treatment to the resident families of } \\
\text { Arunachal Pradesh and first of its kind among } \\
\text { the north eastern states. }\end{array}$ & $\begin{array}{l}\text { Scheme is to provide free } \\
\text { Medical and Surgical treatment } \\
\text { (except Outdoor Patients } \\
\text { facility) in government and } \\
\text { Private hospitals. }\end{array}$ \\
\hline 4 & Assam & Yes & Atal Amrit Abhiyan & $\begin{array}{c}25.12 .2016 \\
2008(R S B Y)\end{array}$ & $\begin{array}{c}\text { BPL and APL families } \\
\text { The beneficiary is any Below Poverty Line } \\
\text { (BPL) family, whose information is included } \\
\text { in the district BPL list prepared by the State } \\
\text { government }\end{array}$ & $\begin{array}{l}\text { The Atal Amril Abhiyan health } \\
\text { insurance scheme would cover } \\
\text { treatment for cancer, kidney } \\
\text { disease, brain and heart- } \\
\text { related ailments and burn } \\
\text { injuries. People suffering from } \\
\text { these diseases would be able } \\
\text { to get treatment at all govt and } \\
\text { CGHS empaneled hospitals for } \\
\text { up to Rs. } 2 \text { Lakh }\end{array}$ \\
\hline 5 & Bihar & Yes & $\begin{array}{l}\text { National Health } \\
\text { Insurance Scheme } \\
\text { (NHIS) }\end{array}$ & 20.08 .2018 & $\begin{array}{l}\text { NHIS for the laborers in the unorganized } \\
\text { sector living below the poverty line in eight } \\
\text { districts of the state }\end{array}$ & $\begin{array}{l}\text { Over } 95 \% \text { of disease } \\
\text { conditions that afflict us are } \\
\text { covered by the NHIS }\end{array}$ \\
\hline 6 & $\begin{array}{c}\text { Chandigarh (Union } \\
\text { Territory) }\end{array}$ & No & $\begin{array}{l}\text { Mukhyamantri Mufat } \\
\text { Ilaj Yojna }\end{array}$ & 1-Jan-14 & Coverage to all the citizens & $\begin{array}{l}\text { Mukhyamantri Muft llaaj } \\
\text { Yojana, the scheme would } \\
\text { cover surgery, drugs, } \\
\text { investigations or diagnostic } \\
\text { services, ambulance or } \\
\text { referral transport services, } \\
\text { indoor services and dental } \\
\text { treatment. It would benefit } 2 \\
\text { crore persons visiting various } \\
\text { Government hospitals in the } \\
\text { state and about } 1 \text { lakh surgery } \\
\text { patients. }\end{array}$ \\
\hline 7 & Chhattisgarh & Yes & & 2008 & $\begin{array}{l}\text { The beneficiary is any Below Poverty Line } \\
\text { (BPL) family, whose information is included } \\
\text { in the district BPL list prepared by the State } \\
\text { government }\end{array}$ & $\begin{array}{l}\text { A package charge means that } \\
\text { all the expenses related to } \\
\text { the treatment like medicine, } \\
\text { tests, bed charges, other } \\
\text { materials, food etc. will be part } \\
\text { of package and hospital will } \\
\text { not charge anything from the } \\
\text { patient for these. }\end{array}$ \\
\hline 8 & $\begin{array}{l}\text { Dadra And Nagar } \\
\text { Haveli (Union } \\
\text { Territory) }\end{array}$ & No & $\begin{array}{c}\text { Sanjeevani Swasthya } \\
\text { Bima Yojana }\end{array}$ & & & \\
\hline 9 & $\begin{array}{c}\text { Daman And Diu(Union } \\
\text { Territory) }\end{array}$ & No & $\begin{array}{c}\text { Sanjeevani Swasthya } \\
\text { Bima Yojana }\end{array}$ & & & \\
\hline 10 & $\begin{array}{l}\text { National Capital } \\
\text { Territory Of Delhi } \\
\text { (Union Territory) }\end{array}$ & No & $\begin{array}{c}\text { Aam Aadmi Swasthya } \\
\text { Bima Yojana }\end{array}$ & & & \\
\hline 11 & Goa & No & $\begin{array}{c}\text { Deen Dayal Swasthya } \\
\text { Seva Yojana }\end{array}$ & 13-Jun-17 & $\begin{array}{c}\text { Deen Dayal Swasthya Seva Yojana is a } \\
\text { scheme to provide health insurance coverage } \\
\text { for the entire resident population of the State } \\
\text { of Goa, Who are residing in Goa for five years } \\
\text { and more. }\end{array}$ & $\begin{array}{l}\text { Quality medical care and } \\
\text { treatment of diseases, } \\
\text { hospitalization and surgery } \\
\text { through Government and } \\
\text { private hospitals. }\end{array}$ \\
\hline 12 & Gujarat & Yes & $\begin{array}{c}\text { Mukhyamantri } \\
\text { Amrutum (MA) Yojana }\end{array}$ & 20- Dec-17 & $\begin{array}{l}\text { The beneficiary is any Below Poverty Line } \\
(\mathrm{BPL}) \text { family, whose information is included } \\
\text { in the district BPL list prepared by the State } \\
\text { government }\end{array}$ & $\begin{array}{l}\text { A package charge means that } \\
\text { all the expenses related to } \\
\text { the treatment like medicine, } \\
\text { tests, bed charges, other } \\
\text { materials, food etc. will be part } \\
\text { of package and hospital will } \\
\text { not charge anything from the } \\
\text { patient for these. }\end{array}$ \\
\hline
\end{tabular}


Citation: Kumar D, Sohal S (2018) Overview of Health Care Expenditure \& Healthcare Payment Methods in India. Health Econ Outcome Res Open Access 4: 154. doi: 10.4172/2471-268x/1000154

Page 3 of 6

\begin{tabular}{|c|c|c|c|c|c|c|}
\hline 13 & Haryana & No & $\begin{array}{l}\text { Mukhyamantri Mufat } \\
\text { Ilaj Yojna }\end{array}$ & 1-Jan-14 & Coverage to all the citizens & $\begin{array}{l}\text { A new health scheme will be } \\
\text { launched in Haryana in the } \\
\text { New Year to provide essential } \\
\text { health care services free of } \\
\text { cost in its all health institutions } \\
\text { from primary to tertiary level }\end{array}$ \\
\hline 14 & Himachal Pradesh & Yes & $\begin{array}{c}\text { RSBY } \\
\text { Mukhya Mantri State } \\
\text { Health Care Scheme } \\
\text { (Himachal Pradesh } \\
\text { Universal Health } \\
\text { Protection Scheme). }\end{array}$ & $\begin{array}{l}\text { Mar 19, } 2016 \\
- \text { MMS 2008- } \\
\quad \text { RSBY }\end{array}$ & $\begin{array}{c}\text { The beneficiary is any Below Poverty Line } \\
(\mathrm{BPL}) \text { family, whose information is included } \\
\text { in the district BPL list prepared by the State } \\
\text { government. }\end{array}$ & $\begin{array}{l}\text { A package charge means that } \\
\text { all the expenses related to } \\
\text { the treatment like medicine, } \\
\text { tests, bed charges, other } \\
\text { materials, food etc. will be part } \\
\text { of package and hospital will } \\
\text { not charge anything from the } \\
\text { patient for these. }\end{array}$ \\
\hline 15 & Jammu And Kashmir & Yes & & Jun-05 & $\begin{array}{l}\text { The beneficiary is any Below Poverty Line } \\
(\mathrm{BPL}) \text { family, whose information is included } \\
\text { in the district BPL list prepared by the State } \\
\text { government. }\end{array}$ & $\begin{array}{l}\text { A package charge means that } \\
\text { all the expenses related to } \\
\text { the treatment like medicine, } \\
\text { tests, bed charges, other } \\
\text { materials, food etc. will be part } \\
\text { of package and hospital will } \\
\text { not charge anything from the } \\
\text { patient for these. }\end{array}$ \\
\hline 16 & Jharkhand & No & $\begin{array}{l}\text { Mukhya Mantri } \\
\text { Swasthya Bima Yojana } \\
\text { (Chief Minister Health } \\
\text { Insurance Scheme) }\end{array}$ & $\begin{array}{l}\text { 15th } \\
\text { November } \\
2017\end{array}$ & Cover the entire state & $\begin{array}{l}\text { The government would } \\
\text { provide health cards to the } \\
\text { beneficiaries and the whole } \\
\text { system would be cashless. }\end{array}$ \\
\hline 17 & Karnataka & Yes & $\begin{array}{l}\text { Suvarna Arogya } \\
\text { Suraksha Trust (Sast), } \\
\text { Universal Health Care } \\
\text { In Karnataka }\end{array}$ & $1 / 4 / 2017$ & $\begin{array}{l}\text { SAST provide Health protection to families } \\
\text { living below poverty line }\end{array}$ & $\begin{array}{l}\text { Government of Karnataka has } \\
\text { taken the initiative to provide } \\
\text { Health protection to families } \\
\text { living below poverty line for the } \\
\text { treatment of major ailments, } \\
\text { requiring hospitalization and } \\
\text { surgery. In order to bridge the } \\
\text { gap in provision of Tertiary } \\
\text { care facility and the specialist } \\
\text { pool of doctors to meet the } \\
\text { statewide requirement }\end{array}$ \\
\hline 18 & Kerala(Rsby-Chis) & Yes & $\begin{array}{l}\text { Comprehensive Health } \\
\text { Insurance Agency } \\
\text { Of Kerala (Chiak), } \\
\text { The Chief Minister's } \\
\text { Distress Relief Fund, } \\
\text { Kerala. }\end{array}$ & $\begin{array}{c}11 / 1 / 2017 \\
2008(R S B Y)\end{array}$ & $\begin{array}{l}\text { The Applicant must be a permanent } \\
\text { resident of Kerala. Candidate should be } \\
\text { government employees and pensioners. } \\
\text { The beneficiary is any Below Poverty Line } \\
\text { (BPL) family, whose information is included } \\
\text { in the district BPL list prepared by the State } \\
\text { government }\end{array}$ & $\begin{array}{l}\text { Kerala Health Insurance } \\
\text { Yojana is to provide } \\
\text { cashless health services } \\
\text { to the employees and } \\
\text { retired employees at } \\
\text { designated hospitals. } \\
\text { A package charge means that } \\
\text { all the expenses related to } \\
\text { the treatment like medicine, } \\
\text { tests, bed charges, other } \\
\text { materials, food etc. will be part } \\
\text { of package and hospital will } \\
\text { not charge anything from the } \\
\text { patient for these. }\end{array}$ \\
\hline 19 & $\begin{array}{l}\text { Lakshadweep(Union } \\
\text { Territory) }\end{array}$ & No & $\begin{array}{l}\text { Insurance Scheme For } \\
\text { Lakshadweep Families }\end{array}$ & & & \\
\hline 20 & Madhya Pradesh & No & $\begin{array}{l}\text { Deendayal Antyodaya } \\
\text { Upchar Yojana The } \\
\text { Scheme }\end{array}$ & $\begin{array}{l}\text { September } \\
\quad 2004\end{array}$ & BPL families & All medical treatment \\
\hline 21 & Maharashtra & No & & 2 July 2012 & $\begin{array}{l}\text { Below Poverty Line and marginally Above } \\
\text { Poverty Line families }\end{array}$ & $\begin{array}{l}\text { It provides free access to } \\
\text { medical care in government } \\
\text { empanelled } 488 \text { hospitals } \\
\text { for } 971 \text { types of diseases, } \\
\text { surgeries and therapies } \\
\text { costing up to Rs. } 1,50,000 \text { per } \\
\text { year per family }\end{array}$ \\
\hline 22 & Manipur & Yes & $\begin{array}{l}\text { Manipur Health } \\
\text { Insurance Scheme }\end{array}$ & Jul 132017 & BPL families & $\begin{array}{l}\text { Treatment like cancer, cardiac } \\
\text { diseases, kidney ailments, } \\
\text { neurological issues, etc could } \\
\text { be the diseases that may be } \\
\text { widely covered under this } \\
\text { insurance scheme. }\end{array}$ \\
\hline 23 & Meghalaya & Yes & $\begin{array}{l}\text { Megha Health } \\
\text { Insurance Scheme } \\
(\mathrm{MHIS})\end{array}$ & $\begin{array}{l}\text { 15th } \\
\text { December, } \\
2012\end{array}$ & $\begin{array}{l}\text { Health insurance to all persons that are } \\
\text { resident in the State excluding state and } \\
\text { central government employees. }\end{array}$ & $\begin{array}{l}\text { To provide financial aid to all } \\
\text { the citizens of the state at the } \\
\text { time hospitalization and reduce } \\
\text { the out-of-pocket expenses of } \\
\text { the residents of the State. }\end{array}$ \\
\hline
\end{tabular}


Citation: Kumar D, Sohal S (2018) Overview of Health Care Expenditure \& Healthcare Payment Methods in India. Health Econ Outcome Res Open Access 4: 154. doi: 10.4172/2471-268x/1000154

\begin{tabular}{|c|c|c|c|c|c|c|}
\hline 24 & Mizoram & Yes & & 2008 & $\begin{array}{l}\text { The beneficiary is any Below Poverty Line } \\
\text { (BPL) family, whose information is included } \\
\text { in the district BPL list prepared by the State } \\
\text { government. }\end{array}$ & $\begin{array}{l}\text { A package charge means that } \\
\text { all the expenses related to } \\
\text { the treatment like medicine, } \\
\text { tests, bed charges, other } \\
\text { materials, food etc. will be part } \\
\text { of package and hospital will } \\
\text { not charge anything from the } \\
\text { patient for these. }\end{array}$ \\
\hline 25 & Nagaland & Yes & & 2008 & $\begin{array}{l}\text { The beneficiary is any Below Poverty Line } \\
\text { (BPL) family, whose information is included } \\
\text { in the district BPL list prepared by the State } \\
\text { government. }\end{array}$ & $\begin{array}{l}\text { A package charge means that } \\
\text { all the expenses related to } \\
\text { the treatment like medicine, } \\
\text { tests, bed charges, other } \\
\text { materials, food etc. will be part } \\
\text { of package and hospital will } \\
\text { not charge anything from the } \\
\text { patient for these. }\end{array}$ \\
\hline 26 & Odisha & Yes & & 2008 & $\begin{array}{l}\text { The beneficiary is any Below Poverty Line } \\
\text { (BPL) family, whose information is included } \\
\text { in the district BPL list prepared by the State } \\
\text { government. }\end{array}$ & $\begin{array}{l}\text { A package charge means that } \\
\text { all the expenses related to } \\
\text { the treatment like medicine, } \\
\text { tests, bed charges, other } \\
\text { materials, food etc. will be part } \\
\text { of package and hospital will } \\
\text { not charge anything from the } \\
\text { patient for these. }\end{array}$ \\
\hline 27 & $\begin{array}{l}\text { Puducherry (Union } \\
\text { Territory) }\end{array}$ & No & $\mathrm{CMCHS}$ & & citizens & $\begin{array}{l}\text { A package includes all the } \\
\text { expenses related to health } \\
\text { care. }\end{array}$ \\
\hline 28 & Punjab & No & $\begin{array}{l}\text { Punjab Government } \\
\text { Employees And } \\
\text { Pensioners } \\
\text { Health Insurance } \\
\text { Scheme (Pgephis) } \\
\text { Care Companion } \\
\text { Programme }\end{array}$ & $2017-2018$ & Punjab's citizens & $\begin{array}{l}\text { Care companion program is a } \\
\text { free in - hospital educational } \\
\text {-cum - training program for } \\
\text { patent's family members. This } \\
\text { program is being developed } \\
\text { for the direct response to } \\
\text { the needs of patient and } \\
\text { recognizes patient family } \\
\text { members as an untapped } \\
\text { existing patients. }\end{array}$ \\
\hline 29 & Rajasthan & Yes & $\begin{array}{c}\text { Rajasthan's Chief } \\
\text { Minister's Relief Fund. }\end{array}$ & 2008 & $\begin{array}{l}\text { The beneficiary is any Below Poverty Line } \\
\text { (BPL) family, whose information is included } \\
\text { in the district BPL list prepared by the State } \\
\text { government. }\end{array}$ & $\begin{array}{l}\text { A package charge means that } \\
\text { all the expenses related to } \\
\text { the treatment like medicine, } \\
\text { tests, bed charges, other } \\
\text { materials, food etc. will be part } \\
\text { of package and hospital will } \\
\text { not charge anything from the } \\
\text { patient for these. }\end{array}$ \\
\hline 30 & Sikkim & No & $\begin{array}{l}\text { Comprehensive Annual } \\
\text { And Total Check-Up } \\
\text { For Healthy Sikkim } \\
\text { (Catch) }\end{array}$ & 26-Aug-10 & $\begin{array}{l}90 \text { percent of the population in Sikkim has } \\
\text { been covered under CATCH to compile their } \\
\text { health profile. }\end{array}$ & $\begin{array}{l}\text { This is path-breaking initiative } \\
\text { provides comprehensive } \\
\text { care with focus on health } \\
\text { promotions and prevention by } \\
\text { doing annual and periodical } \\
\text { head to toe health checkup } \\
\text { free of cost for all citizens of } \\
\text { Sikkim }\end{array}$ \\
\hline 31 & Tamil Nadu & No & $\mathrm{CMCHS}$ & & Family income less than Rs. 72000 Per annum & $\begin{array}{l}\text { A package includes all the } \\
\text { expenses related to health } \\
\text { care. }\end{array}$ \\
\hline 32 & Telangana & No & Aarogyasri Health Care & & $\begin{array}{l}\text { The scheme provides financial protection to } \\
\text { families living below poverty line. }\end{array}$ & $\begin{array}{l}\text { The scheme provides } \\
\text { coverage for the systems } \\
\text { like Heart, Lung, Liver, } \\
\text { Pancreas, Kidney, Neuro- } \\
\text { Surgery, Pediatric Congenital } \\
\text { Malformations, Burns, Post } \\
\text {-Burn Contracture Surgeries } \\
\text { for Functional Improvement, } \\
\text { Prostheses (Artificial limbs), } \\
\text { Cancer treatment (Surgery, } \\
\text { Chemo Therapy, Radio } \\
\text { Therapy ), Polytrauma } \\
\text { (including cases covered under } \\
\text { MV Act) and Cochlear Implant } \\
\text { Surgery with Auditory-Verbal } \\
\text { Therapy for Children below } \\
2 \text { years. All the pre-existing } \\
\text { cases of the above mentioned } \\
\text { diseases are covered under } \\
\text { the scheme. }\end{array}$ \\
\hline
\end{tabular}




\begin{tabular}{|c|c|c|c|c|c|c|}
\hline 33 & Tripura & Yes & $\begin{array}{l}\text { Tripura Health } \\
\text { Assurance Scheme for } \\
\text { Poor (THASP) }\end{array}$ & 2008 & $\begin{array}{c}\text { The beneficiary is any Below Poverty Line } \\
\text { (BPL) family, whose information is included } \\
\text { in the district BPL list prepared by the State } \\
\text { government. }\end{array}$ & $\begin{array}{l}\text { THASP covers cancer, } \\
\text { cardiovascular surgeries, } \\
\text { neurosurgeries, kidney-related } \\
\text { diseases, poly-trauma, neo- } \\
\text { natal diseases, and ophthalmic } \\
\text { disorder. THASP will not cover } \\
\text { accident cases. }\end{array}$ \\
\hline 34 & Uttar Pradesh & No & Sachi-RSBY & 2008 & $\begin{array}{l}\text { Only registered BPL families are eligible for } \\
\text { RSBY Smart Card }\end{array}$ & $\begin{array}{l}\text { A package charge means that } \\
\text { all the expenses related to } \\
\text { the treatment like medicine, } \\
\text { tests, bed charges, other } \\
\text { materials, food etc. will be part } \\
\text { of package and hospital will } \\
\text { not charge anything from the } \\
\text { patient for these. }\end{array}$ \\
\hline 35 & Uttarakhand & Yes & MSBY & 2008 & $\begin{array}{c}\text { The beneficiary is any Below Poverty Line } \\
(\mathrm{BPL}) \text { family, whose information is included } \\
\text { in the district BPL list prepared by the State } \\
\text { government. }\end{array}$ & $\begin{array}{l}\text { A package charge means that } \\
\text { all the expenses related to } \\
\text { the treatment like medicine, } \\
\text { tests, bed charges, other } \\
\text { materials, food etc. will be part } \\
\text { of package and hospital will } \\
\text { not charge anything from the } \\
\text { patient for these. }\end{array}$ \\
\hline 36 & West Bengal & Yes & $\begin{array}{l}\text { Swasthya Sathi } \\
\text { Scheme }\end{array}$ & $\begin{array}{c}2016 \\
2008(R S B Y)\end{array}$ & $\begin{array}{l}\text { The West Bengal Government has extended } \\
\text { the coverage of its Swasthya Sathi health } \\
\text { insurance scheme, to include several } \\
\text { more categories of the State Government } \\
\text { employees. The health security scheme } \\
\text { would now cover } 55.5 \text { lakh more government } \\
\text { employees. }\end{array}$ & $\begin{array}{l}\text { Basic health covers for } \\
\text { secondary and tertiary care. } \\
\text { All pre-existing diseases are } \\
\text { covered. }\end{array}$ \\
\hline
\end{tabular}

Table 1: Types of Health Insurance Schemes in India

certainly a limitation in reimbursement to allowable costs, the payer makes periodic interim payments (PIPs) to the provider, and a final reconciliation is made after the contract period expires and all costs have been processed through the provider's managerial (cost) accounting system [18]. The payment of billed charges, or simply charges by payers are paid according to a rate schedule established by the provider, called a charge master. To a certain extent, in this reimbursement system payers are often placed at the mercy of providers in regard to the cost of healthcare services, especially in markets with limited competition. The prospective payments consist of per deim, per procedure, bundled, per diagnosis. In fee for service financial risk rests with the payer and low risk with the provider. This may encourage over servicing and unnecessary interventions. For the providers, billing procedures are costly and for the insurer, the cost of processing claims is high. The payer/insurer must establish expensive monitoring procedures to minimize false claims [19].

In pay for performance administrative burden is on providers and insurers, is costly and require substantial additional investment in information technology to monitor performance. Providers may Increase the number of services that lead to improved performance indicator thus gaining acceptance from providers [18].

\section{Per-diem payment method}

Per-diem payment method is being used more for hospitals as compared to capitation methods probably due to length of stay so that health insurance plans prefer to "rent beds" on required basis. Information is missing regarding frequency of use of budget approaches. Hence, it is important to note, however, that most healthcare providers receive payment from a variety of payers that may rely on different methods. Thus, any given provider faces a mix of incentives and rewards, rather than a consistent set of expectations. A well-designed payment mechanism should be able to meet objectives of quality, efficiency and accessibility. It must also take into consideration the management capacity and systems of both the financier and health providers. Competition among providers tends to promote quality and consumer satisfaction and no single provider payment method provides all the right incentives, a combination of payment methods may be necessary. The typical payment for the physician is through feefor-service methods and hospitals through billed (discounted) charges, per diem or per case. Some surveys suggest increase in capitation for physicians nevertheless, other sources suggest its use may be flat or decreasing [21].

\section{Conclusion}

To reduce out of pocket expenditure there is an urgent need for significant reforms, and to contribute to this are payment methods such as prospective and retrospective. In reimbursement approach funding is retrospective to providers for services delivered. In worldwide the primary and essential role of the health care system is not only providing the preventive and curative care it also includes protect the people from catastrophic health expenditure by the proper funding mechanism to an individual to acquire health care [22].

\section{References}

1. Accounts HK (2004) Estimates of Domestic Health Expenditure. Hong Kong's: Domestic Health Accounts.

2. Xu K, Evans DB, Kawabata K, Zeramdini R, Klavus J, et al. (2003) Household catastrophic health expenditure: a multicountry analysis. 111-117.

3. Xu K, Evans DB, Carrin G, Aguilar-Rivera AM, Musgrove P, et al. (2007) Protecting households from catastrophic health spending 26: 972-983.

4. Timothy (2007) Protecting households from catastrophic health Spending Health Systems and Policy Research pp: 1-3.

5. Wagstaff A, van Doorslaer E (2003) Catastrophe and impoverishment in paying for health care: with applications to Vietnam. Health Econ 12: 921-934.

6. Organization WH (2003) The world health report 2003 - shaping the future.

7. Su TT, Kouyaté B, Flessa S (2006) Catastrophic household expenditure for health care in a low income society: a study from Nouna District. Burkina Faso. Bull World Health Organ 84: 21-27. 
Citation: Kumar D, Sohal S (2018) Overview of Health Care Expenditure \& Healthcare Payment Methods in India. Health Econ Outcome Res Open Access 4: 154. doi: 10.4172/2471-268x/1000154

Page 6 of 6

8. Van Doorslaer E, O'Donnell O, Rannan-Eliya RP, Somanathan A, Adhikari SR, et al. (2006) Effect of payments for health care on poverty estimates in 11 countries in Asia: an analysis of household survey data. Lancet 368: 13571364.

9. Shahrawat R, Rao KD (2012). Insured yet vulnerable: out-of-pocket payments and India's poor. Health Policy Plan 27: 213-221.

10. Dalal K, Aremu O, Ussatayeva G, Biswas A (2017) Out-of-pocket health expenditure and fairness in utilization of health care facilities in Cambodia in 2005 and 2010. F1000 Res 6: 2066.

11. Quinn K (2015) The 8 Basic Payment Methods in Health Care. Annals of Internal Medicine.

12. Arhin-Tenkorang D (2000) Mobilizing Resources for Health: The Case for User Fees Revisited. Center for International Development at Harvard University pp: 3-20.

13. Arhin-Tenkorang D (2001) Mobilizing resources for health: the case for user fees revisited. Center for International Development at Harvard University pp: $1-17$.

14. Drew B, Angeli F, Dave K, Pavlova M (2016) Impact of patients' healthcare payment methods on hospital discharge process:evidence from India. Int $J$ Health Plann Mgmt 31: 158-174
15. Dieleman DJ (2018) Trends in future health financing and coverage: future health spending and universal health coverage in 188 countries, 2016-40. Global Burden of Disease Health Financing Collaborator Network 391: 1783 1798.

16. Health Insurance in India (2012) Retrieved from shodhganga.inflibnet.ac.in.

17. Langenbrunner JC, Liu X (2004) How To Pay? Understanding and Using Incentives. World bank.

18. Rukwaro DE (2012) Provider payment mechanisms.

19. Gapenski LC (2012) Healthcare Finance: An Introduction to Accounting and Financial Management Hardcover.

20. Berenson RA, Delbanco SF, Upadhyay DK, Roslyn Murray (2016) Payment Methods and Benefit Designs: How They Work and How They Work Together to Improve Health Care. Urban Institute and catalyst for payment reforms.

21. Richardson WC (2001) Crossing the Quality Chasm: A New Health System. Washington, D.C. National Academy Press.

22. Fazaeli AA, Hadian M, Rezapour A, Fazaeli AA (2016) Assessing the Distribution of Household Financial Contribution to Health System: A Case Study of Iran. Global J Health Sci 8: 223-236. 